\title{
THE POTENTIAL OF ORIGANUM VULGARE L. (LAMIACEAE) ESSENTIAL OIL IN INHIBITING THE GROWTH OF SOME FOOD-RELATED ASPERGILLUS SPECIES
}

\author{
Egberto Santos Carmo; ${ }^{1}$ Edeltrudes de Oliveira Lima ${ }^{2}$; Evandro Leite de Souza ${ }^{3}$
}

\begin{abstract}
${ }^{1}$ Laboratório de Tecnologia Farmacêutica, Universidade Federal da Paraíba, João Pessoa, PB, Brasil; ${ }^{2}$ Laboratório de Micologia, Departamento de Ciências Farmacêuticas, Centro de Ciências da Saúde, Universidade Federal da Paraíba, João Pessoa, PB, Brasil; ${ }^{3}$ Departamento de Nutrição, Centro de Ciências da Saúde, Universidade Federal da Paraíba, João Pessoa, PB, Brasil.
\end{abstract}

Submitted: March 15, 2007; Approved: February 11, 2008.

\begin{abstract}
Origanum vulgare L. (Lamiaceae) has been currently known for their interesting antimicrobial activity being regarded as alternative antimicrobial for use is food conservation systems. This study aimed to evaluate the effectiveness of $O$. vulgare essential oil in inhibiting the growth of some food-related Aspergillus species (A. flavus, A. parasiticus, A. terreus, A. ochraceus, A. fumigatus and A. niger). The essential oil revealed a strong anti-Aspergillus property providing an inhibition of all assayed mould strains. MIC values were between 80 and $20 \mu \mathrm{L} / \mathrm{mL}$ being found a $\mathrm{MIC}_{50}$ of $40 \mu \mathrm{L} / \mathrm{mL}$. The essential oil at concentration of 80 and $40 \mu \mathrm{L} / \mathrm{mL}$ provided a fungicidal effect on $A$. flavus, A. fumigatus and A. niger noted by a total inhibition of the radial mycelial growth along 14 days of interaction. In addition, the essential oil was able to inhibit the mould spores germination when assayed at concentrations of 80 and $40 \mu \mathrm{L} / \mathrm{mL}$. Our results showed the interesting anti-Aspergillus activity of $O$. vulgare essential oil supporting their possible use as anti-mould compound in food conservation.
\end{abstract}

Key-words: $O$. vulgare, essential oil, Aspergillus

\section{INTRODUCTION}

Moulds are ubiquitously distributed in nature and their spores can be found in the atmosphere even at high altitudes, carried and disseminated by wind and air currents, as well as can be spread by insects, rodents, and other animals. The metabolic activities accompanying the growth and mould development decomposes organic substrate ensuring the recycling of elements that comprise organic matters. Food products, being organic substances and containing essential nutrients, are very suitable substrates for the mould growth $(13,15,28)$. Because their powerful arsenal of hydrolytic enzymes, moulds can cause a high degree of deterioration when present in/on foods and can be responsible for considerable economic losses. However, some people see actually to prefer, on the basis of flavor, foods with a touch of mouldiness, while mould cultures have been frequently used in the preparation of various traditional fermented foods $(14,21)$.

Besides the possible food decaying caused by moulds and ultimate changes in it nutritional and organoleptical characters, the moldiness in foodstuffs is toxicologically significant since the mould species growing on such products is known as potentially mycotoxicogenic $(4,15)$. Mycotoxins are toxic metabolites produced by filamentous fungi that have been detected in several food commodities. Levels of mycotoxins and mycotoxicogenic moulds, which can cause risk to population, are refused by consumers and many countries have set regulations in various agricultural foods. The consumption of mouldy products can cause human or animal mycotoxicoses, and more important some mycotoxins are potent carcinogens $(3,14,23,36)$.

Aspergillus genus, which presents species inserted in the group of infesting living plants/field fungi (e.g. A. flavus) and

*Corresponding Author. Mailing address: Universidade Federal da Paraíba, Departamento de Nutrição, Cidade Universitária, Campus I, Castelo Branco III, Cep 58000-000, João Pessoa, PB, Brasil. Tel.: 8332167499 Fax: 83 32167499. E-mail: evandroleitesouza@ccs.ufpb.br 
infesting stored food products/storage fungi (e.g. A. parasiticus, A. ochraceus, A. fumigatus, A. chevalieri and A. clavatus), is responsible for many causes of food contaminations all over the world $\left(1,36\right.$ ). Aflatoxins- $\mathrm{B}_{1}, \mathrm{~B}_{2}, \mathrm{G}_{1}, \mathrm{G}_{2}$ (produced by A.flavus and $A$. parasiticus), aspergillic acid (produced by $A$. flavus), hidroxiaspergillic acid (produced by $A$. flavus), ascladiol (produced by A. clavatus), gliotoxin (produced by A.fumigatus, A. chavalieri and A.terreus), austamide (produced by A. usutus), ochratoxins (produced by $A$. ochraceus), oxalic acid (produced by A. flavus and A. glaucus), terreic acid (produced by A. terreus) are some mycotoxins produced by Aspergillus species in foods when exposed to suitable conditions $(13,15,17)$.

Chemicals are used to inhibit the fungal growth in/on foods, however the negative consumer perception of chemical preservatives drives attention toward natural alternatives, so that many researches worldwide have been carried out in order to evaluate the effectiveness of many plant products in inhibiting the growth of spoiling and/or pathogen food-related microorganisms. Origanum vulgare L., Lamiaceae family, is widely known as a very versatile plant with many therapeutic properties (diaphoretic, carminative, antispasmodic, antiseptic, tonic) being applied in traditional medicine systems in many countries $(26,27)$. It has been widely used in agricultural, pharmaceutical and cosmetic industries as culinary herb, flavoring substances in food products, alcoholic beverages and perfumery for its spicy fragrance $(2,12,20)$. Although, some researchers have found antimicrobial activity in Origanum vulgare $\mathrm{L}$. $(6,9,19,30)$, there is a lack of information about their effect on the kinetic of the mycelial growth and mould spores germination of Aspergillus species.

The aim of this study was to evaluate the effect of Origanum vulgare $\mathrm{L}$. essential oil on some aspects related to the growth of some Aspergillus species recognized as potential foodcontaminating.

\section{MATERIALAND METHODS}

\section{Essential oil}

Origanum vulgare L. essential oil was supplied by Ferquima Ind. Com. Ltda. (Vargem Grande Paulista, São Paulo, Brazil) and its quality parameters: appearance, color, purity, odor, density $20^{\circ} \mathrm{C}$, refraction index $-20^{\circ} \mathrm{C}$ were described in an accompanying technical report. This provider produces and commercializes essential oils on an industrial scale. The essential oil was assayed at concentrations of $320,160,80,40,20,10$ and $5 \mu \mathrm{L} / \mathrm{mL}$ and the solutions were prepared according to Souza et al., (36).

\section{Moulds strains}

Aspergillus fumigatus (ATCC-16913 and ATCC-40640), A. niger (P-03 and LM-257), A. flavus (ATCC-16013 and LM-247), A. parasiticus (ATCC-15517 and NRRL-2999), A. terreus (UP03 and ATCC-7860) and A. ochraceus (ATCC-7860 and LM-06) strains were used as test microorganisms. These strains were taken from the Microorganisms Collection, Laboratory of Mycology, Department of Pharmaceutical Sciences, Health Sciences Center, Federal University of Paraíba, Brazil. Stock cultures were maintained on Sabouraud agar (SA) slants and stored in a refrigerator.

\section{Minimum Inhibitory Concentration - MIC}

The essential oil MIC was found by a qualitative method using the solid medium diffusion procedure $(31,32)$. For this, 1 $\mathrm{mL}$ of mould homogenous suspension (approximatelly $10^{6}$ spores $/ \mathrm{mL}$ ) prepared according to Rana et al. (22) was uniformly spread on sterile SA Petri dishes. After inoculum absorption by SA, wells were made using sterile glass stems (diameter $6 \mathrm{~mm}$ ) which were filled with $50 \mu \mathrm{L}$ of the essential oil solution at different concentrations. The incubation period was 7-10 days at $25^{\circ} \mathrm{C}$. At the end of the incubation period, the MIC was the lowest essential oil concentration showing growth inhibition zones with diameter equal to or greater than $10 \mathrm{~mm}$.

Control was carried out with amphotericin B $(100 \mu \mathrm{g} / \mathrm{mL})$ and ketoconazole $(50 \mu \mathrm{g} / \mathrm{mL})$ by solid medium diffusion procedure using filter paper discs (Cecon, diameter $6 \mathrm{~mm}$ ) (5). Also, it was carried out the control of viability of the assayed mould strains by observing their capability of growing on SA without adding essential oil or standard antifungical. Each assay was performed twice and the results were expressed as the average of the two repetitions.

\section{Mycelial growth inhibition}

Inhibition of the dematiaceous mould mycelial growth was determined using the poisoned substrate technique by the daily measure of the radial mycelial growth on SA added of the essential oil in an amount adjusted to provide a final concentration similar to the MIC previously found $(1,10)$. For this, a $2 \mathrm{~mm}$ plug taken from a 10-days-old mould culture cultivated on SA slants were placed on the center of the sterile SA Petri dishes added of the essential oil prior to the assay and incubated at $25-27^{\circ} \mathrm{C}$ for 10 days. At different intervals $(0,2,4,6$, $8,10,12$ and 14 days) after incubation, the mould radial mycelial growth was measured $(\mathrm{mm})$ using calipers. Control included in this assay was the observation of the mould radial growth on SA without adding essential oil, and added of ketoconazole (50 $\mu \mathrm{g} / \mathrm{mL}$ ). Each assay was performed twice and the results were expressed as the average of the two repetitions.

\section{Spore germination assay}

Different concentrations of the essential oil were tested for spore germination of the assayed mould strains. Aliquots of 0.2 $\mathrm{mL}$ of the essential oil solutions at different concentration were mixed with $0.2 \mathrm{~mL}$ of the mould spores suspension (approximatelly $10^{5}$ spores $/ \mathrm{mL}$ ) followed by shaking using Vortex for 30 seconds. $0.1 \mathrm{~mL}$ of the mixture was placed on separated glass slides which 
were incubated in a moist chamber at $25 \pm 2^{\circ} \mathrm{C}$ for 24 hours. At the end of the incubation period, each slide was fixed with lactophenol-cotton blue stain and observed under the microscope for spore germination. About 200 spores were counted and the per cent spore germination was calculated in comparison with the control assay where the essential oil was replaced for sterile distilled water $(22,29)$. Each assay was performed twice and the results were expressed as the average of the two repetitions.

\section{Statistical analysis}

Statistical analysis was performed to determine significant differences $(\mathrm{P}<0.05)$ by Tukey test in the mould mycelial radial growth assays. For this was used Sigma stat 2.03 computer program.

\section{RESULTS AND DISCUSSION}

In the last years the scientific literature in food science and technology has emphasized the antimicrobial activity of essential oils regarding their use in the named food bioconservation systems. Food bioconservation is a widely accepted system being referred as a natural procedure able to provide the extension of the shelf-life and food microbial safety $(25,24,34)$. In this renewed interest, $O$. vulgare essential oil has been known as interesting source of antimicrobial compounds to use in food conservation $(10,20,32,33)$.

Results of the inhibitory activity of $O$. vulgare essential oil on the growth of 12 Aspergillus species strains in solid medium are shown in Table 1. Fungal growth inhibition was noted in all assayed Aspergillus species being found a dose dependent anti-mould activity. On the basis of mould growth inhibition zones, various concentrations $(320-40 \mu \mathrm{L} / \mathrm{mL})$ of $O$. vulgare essential oil showed a very strong anti-mould activity. At concentrations from 320 to $80 \mu \mathrm{L} / \mathrm{mL}$ the essential oil inhibited all assayed strains providing the development of wide growth inhibition zones $(10-25 \mathrm{~mm})$. On the other hand, all tested moulds strains were resistant to concentration of 10 and $5 \mu \mathrm{L} /$ $\mathrm{mL} .40 \mu \mathrm{L} / \mathrm{mL}$ was the $\mathrm{MIC}_{50}$ (concentration of the essential oil causing a growth inhibition of $50 \%$ or more of the assayed strains) found to $O$. vulgare essential oil. The lowest MIC values $(10 \mu \mathrm{L} / \mathrm{mL})$ were found at interactions with $A$. niger P-03 and $A$. flavus LM-247.

In some assayed concentrations ( 320 to $40 \mu \mathrm{L} / \mathrm{mL}$ ) the essential oil provided the development of fungal growth inhibition zones with diameter equal to or higher than the ones found to the tested standard antifungicals (amphotericin B and ketoconazole). Amphotericin B showed a weak capacity in inhibiting the mould growth with inhibition zones showing diameters between 0 and $12 \mathrm{~mm}$.

Study of kinetic of mould growth (Fig. 1, 2 and 3) assessed by radial mycelial growth $(\mathrm{mm})$ measure along different time intervals revealed a fungicidal effect of $O$. vulgare essential oil when assayed in the $80\left(\mathrm{MIC}_{50}\right.$ value $)$ and $40 \mu \mathrm{l} / \mathrm{mL}$ on A. flavus, A. fumigatus and $A$. parasiticus. The essential oil provided significant $(\mathrm{P}<0.05)$ reduction in the mycelial mould growth when compared with the control assay and ketoconazole. O. vulgare provided $100 \%$ of lethal effect already after 2 days of interactions and no mycelial growth occurred in the later times. These

Table 1. Inhibitory effect of $O$. vulgare essential oil on the growth of some Aspergillus species (results expressed in millimeters of mould growth inhibition zones).

\begin{tabular}{|c|c|c|c|c|c|c|c|c|c|c|}
\hline \multirow[b]{2}{*}{ Mould strains } & \multicolumn{7}{|c|}{ O. vulgare essential oil $(\mu \mathrm{L} / \mathrm{mL})$} & \multicolumn{3}{|c|}{ Control } \\
\hline & 320 & 160 & 80 & 40 & 20 & 10 & 5 & $\begin{array}{c}\text { Amph B }{ }^{\mathrm{a}} \\
(100 \mu \mathrm{g} / \mathrm{mL})\end{array}$ & $\begin{array}{c}\text { Ketoc }^{\mathrm{b}} \\
(50 \mu \mathrm{g} / \mathrm{mL})\end{array}$ & $\operatorname{Viab}^{\mathrm{c}}$ \\
\hline A. fumigatus ATCC-16913 & 25 & 20 & 20 & 8 & 0 & 0 & 0 & 8 & 18 & + \\
\hline A. fumigatus ATCC-40640 & 18 & 15 & 12 & 7 & 0 & 0 & 0 & 0 & 10 & + \\
\hline A. niger $\mathrm{P}-03$ & 24 & 17 & 15 & 12 & 10 & 0 & 0 & 12 & 10 & + \\
\hline A. niger LM-257 & 27 & 25 & 21 & 13 & 0 & 0 & 0 & 8 & 10 & + \\
\hline A. flavusATCC-16013 & 27 & 24 & 20 & 10 & 0 & 0 & 0 & 7 & 22 & + \\
\hline A.flavus LM-247 & 30 & 22 & 20 & 12 & 10 & 0 & 0 & 7 & 15 & + \\
\hline A. parasiticus ATCC-15517 & 16 & 15 & 14 & 12 & 0 & 0 & 0 & 8 & 20 & + \\
\hline A. parasiticusNRRL-2999 & 18 & 14 & 12 & 8 & 0 & 0 & 0 & 7 & 20 & + \\
\hline A.terreus UP-03 & 23 & 20 & 17 & 15 & 8 & 0 & 0 & 0 & 15 & + \\
\hline A. terreus ATCC-7860 & 24 & 20 & 17 & 10 & 7 & 0 & 0 & 0 & 20 & + \\
\hline A. ochraceus ATCC-7860 & 18 & 14 & 10 & 8 & 0 & 0 & 0 & 7 & 12 & + \\
\hline A. ochraceus LM-06 & 24 & 18 & 14 & 10 & 8 & 0 & 0 & 0 & 12 & + \\
\hline
\end{tabular}

${ }^{\mathrm{a}}$ amphotericin B; ${ }^{\mathrm{b}}$ ketoconazole; ${ }^{\mathrm{c}}$ strain viability: ability of the strain to grow in Sabouraud agar without adding essential oil or synthetic antibiotic. 


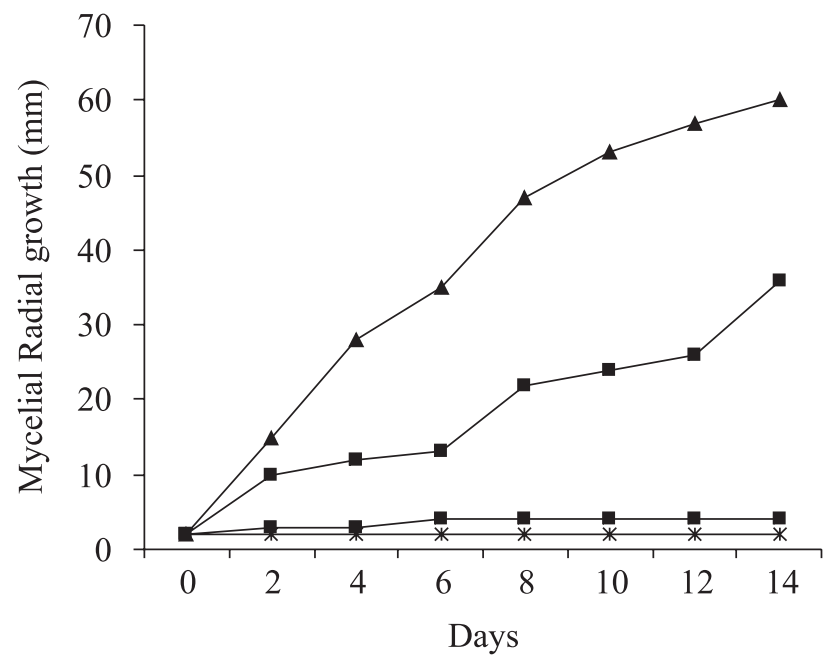

* Essential oil $(80 \mu \mathrm{g} / \mathrm{mL}) \rightarrow$ Essential oil $(40 \mu \mathrm{g} / \mathrm{mL})$

$\rightarrow$ Ketoconazole $(100 \mu \mathrm{g} / \mathrm{mL}) \rightarrow$ Control

Figure 1. Effect of $O$. vulgare essential oil and ketoconazole on the radial mycelial growth kinetic of A. flavus LM-247.

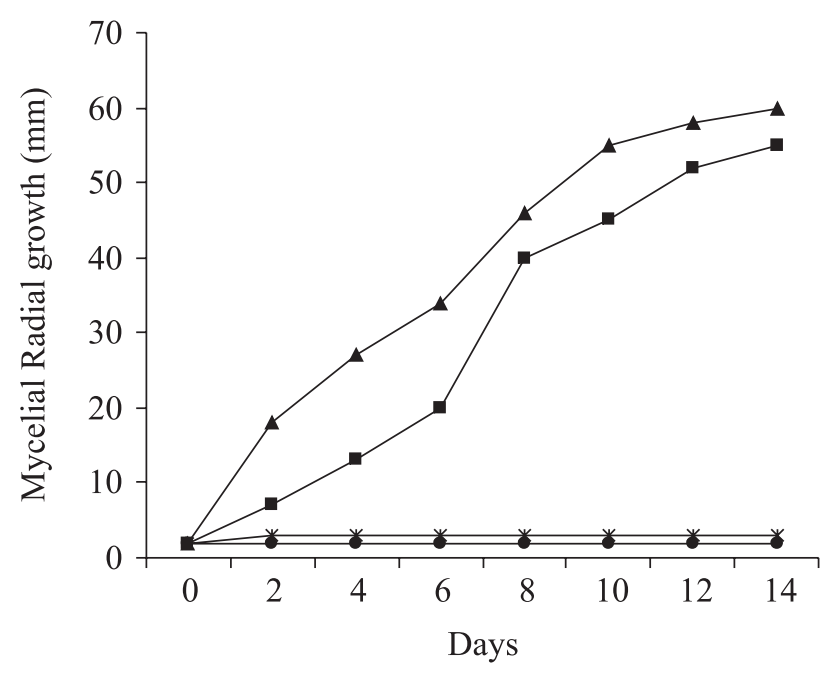

$\rightarrow$ Essential oil $(80 \mu \mathrm{g} / \mathrm{mL}) \rightarrow$ Essential oil $(40 \mu \mathrm{g} / \mathrm{mL})$
$\rightarrow$ Ketoconazole $(100 \mu \mathrm{g} / \mathrm{mL}) \rightarrow$ Control

Figure 2. Effect of $O$. vulgare essential oil and ketoconazole on the radial mycelial growth kinetic of A. fumigatus ATCC-40640.

findings show an intense fumigant property of $O$. vulgare essential oil being a fast and steady rate of mycelial growth inhibition a characteristic of the essential oil. Only in the assay with A. flavus LM-247 was noted a slow and small increase (2 to

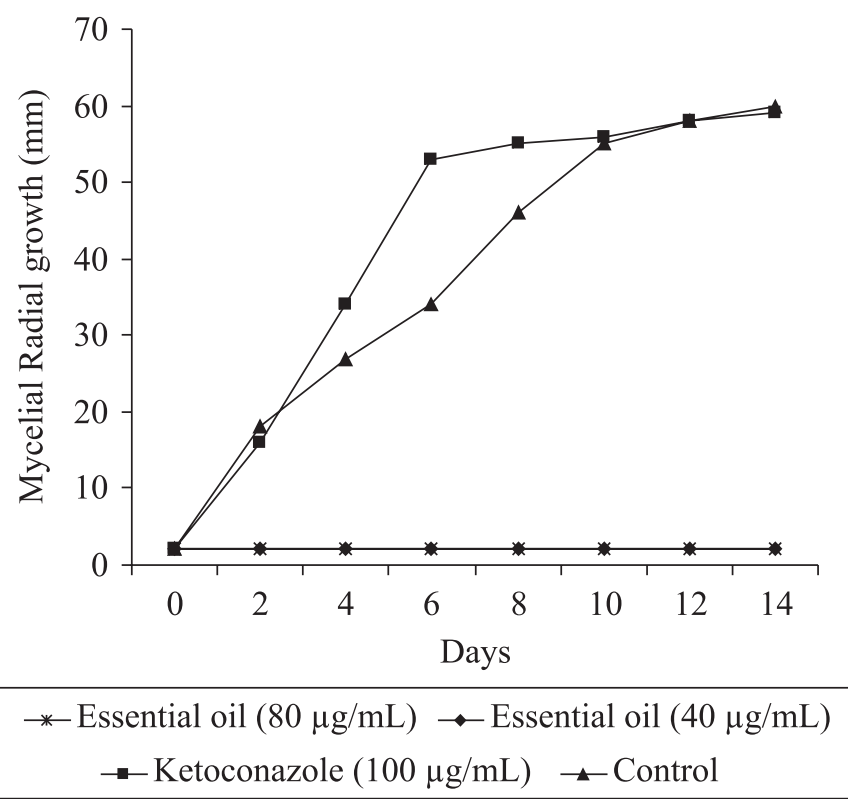

Figure 3. Effect of $O$. vulgare essential oil and ketoconazole on the radial mycelial growth kinetic of $A$. niger $\mathrm{P}-03$.

$4 \mathrm{~mm}$ ) in the mycelial growth up to 6 days of exposure when the essential oil was assayed at concentration of $40 \mu \mathrm{L} / \mathrm{mL}$.

Ketoconazole was included in the mould growth kinetic assay because no assayed mould presented resistance to it in the MIC assay. Ketoconazole showed no significant $(\mathrm{P}<0.05)$ inhibition of the radial mycelium growth. All tested mould presented a progressive mycelial growth when in exposure to ketoconazole along the evaluated time intervals.

The results of the effect of $O$. vulgare essential oil at concentrations of 40 and $80 \mu \mathrm{L} / \mathrm{mL}$ on the spore germination of A. parasiticus. As can be noted the essential oil exhibited a strong inhibition of spore germination of all tested fungi by both assayed concentrations. A $100 \%$ inhibition was found at $80 \mu \mathrm{L} / \mathrm{mL}$ on $A$. niger, while at $40 \mu \mathrm{L} / \mathrm{mL}$ concentration the inhibition was always over $90 \%$. In addition, it was noted that those spores which germinated in presence of the essential oil produced smaller germ tubes (early growing hyphae) as compared with the control assay (data not shown). In agreement with earlier researches $(22,29)$ the inhibition of spore germination caused by $O$. vulgare essential oil was in a dosage response manner.

Earlier studies have noted the effectiveness of some essential oils in inhibiting the growth and mycotoxins synthesis of some food-related moulds in laboratorial media and foodstuffs. Basílico and Basílico (3) and Velluti et al. (35) found significant inhibitory effect of $O$. vulgare essential oil on the growth of Fusarium proliferatum and Aspergillus ochraceus and ochratoxin A and fumonisin $\mathrm{B}_{1}$, respectively. On the other hand, 
Table 2. Inhibition of $O$. vulgare essential oil on spore germination of Aspergillus species (results expressed in percent of spore germination inhibition in comparison with the control assay).

\begin{tabular}{ccc}
\hline \multirow{2}{*}{ Moulds } & \multicolumn{2}{c}{$\begin{array}{c}\text { O. vulgare essential oil } \\
\text { (concentrations) }\end{array}$} \\
\cline { 2 - 3 } & $40 \mu \mathrm{L} / \mathrm{mL}$ & $80 \mu \mathrm{L} / \mathrm{mL}$ \\
\hline A. flavus $\mathrm{LM}-247$ & $91 \%$ & $100 \%$ \\
A. fumigatus ATCC-40640 & $93 \%$ & $100 \%$ \\
A. niger $\mathrm{P}-03$ & $100 \%$ & $100 \%$ \\
\hline
\end{tabular}

Marín et al. (17) noted a poor efficacy of $O$. vulgare essential oil to inhibit the growth of Fusarium graminearum and production of zearalenone and deoxynivalenol.

Essential oils presenting high amount of phenolic compounds have showed the greatest anti-mould activities. Some researchers have reported high content of phenolic compounds in $O$. vulgare essential oil, mostly thymol and carvacrol, which are probably mainly responsible for its prominent antimicrobial effect. $o$-cymene, $p$-cymene, á-pinene, myrcene, ã-terpinene, canfene, limonene, trans-caryophyllene, borneol, linalool and cineole are some minority compounds found in $O$. vulgare essential oil $(19,32)$.

Phenolic compounds, in appropriate concentration and prolonged application, are effective against several microorganisms (8). Their mechanism of antimicrobial activity is related to protoplasmic poisoning, disruption of microbial cell wall, and precipitation of cell protein $(7,8)$. In addition, the antimicrobial activity of these compounds has been attributed to the presence of an aromatic nucleus and an $\mathrm{OH}$ group known to be reactive and to form hydrogen bonds with active sites of target enzymes (35).

It has been found that essential oils with anti-mould effectiveness is able to consistently cause morphological changes in Aspergillus species including lack of sporulation, loss of pigmentation, aberrant development of conidiophores (flattened and squashed) and distortion of hyphaes (budding, lack of cytoplasm, swelling anomalous apex bifurcation) $(11,16,23,29)$. These findings suggested that the mode of antifungal activity of essential oils could include an attack on the cell wall and retraction of the cytoplasm in the hyphae ultimately resulting in death of the mycelium. In addition, it was also related to the interference of the essential oil components in enzymatic reactions of wall cell synthesis, which affects the fungal growth and morphogenesis.

The results found in this study showed a fungicidal activity of $O$. vulgare essential oil providing interesting information about rapidity and stability of its anti-Aspergillus property. It also showed that the growth and survival of spoiling and food- related Aspergillus species in foods could be controlled by the use of essential oils, particularly, $O$. vulgare essential oil. Regarding our results, further researches are being designed to assess the interference of $O$. vulgare essential oil in the mycotoxin synthesis of some toxicogenic Aspergillus species.

\section{RESUMO}

\section{Potencial do óleo essencial de Origanum vulgare $\mathrm{L}$. (Lamiaceae) em inibir o crescimento de algumas cepas de Aspergillus de interesse em alimentos}

Origanum vulgare L. (Lamiaceae) tem sido atualmente reconhecido por sua intensa atividade antimicrobiana sendo considerado como fonte de compostos antimicrobianos alternativos para uso em sistemas de conservação de alimentos. Este estudo objetivou avaliar a efetividade do óleo essencial de $O$. vulgare em inibir o crescimento de algumas espécies de Aspergillus (A. flavus, A. parasiticus, A. terreus and A. fumigatus) de interesse em alimentos. O óleo essencial revelou uma forte atividade atni-Aspergillus provocando a inibição de todas as cepas fúngicas ensaiadas. Os valores de MIC estiveram entre 80 e $20 \mu \mathrm{L} / \mathrm{mL}$ sendo encontrado uma $\mathrm{MIC}_{50}$ de $40 \mu \mathrm{L} / \mathrm{mL}$. O óleo essencial nas concentrações de 80 e $40 \mu \mathrm{L} / \mathrm{mL}$ causou um efeito fungicida sobre A. flavus, A. fumigatus e A. niger notado por uma total inibição do crescimento micelial radial ao longo de 14 dias de interação, bem como foi capaz de inibir a germinação de esporos destas cepas fúngicas. Nossos resultados mostram a intensa atividade anti-Aspergillus do óleo essencial de $O$. vulgare suportando o seu possível uso como antifúngico em sistemas de conservação de alimentos.

Palavras-chave: O. vulgare, essential oil, Aspergillus

\section{REFERENCES}

1. Adam, K.; Sivropoulou, A.; Kokkini, S.; Lanaras, T.; Arsenakis, M. (1998). Antifungal activities of Origanum vulgare subsp. hirtum, Mentha spicata, Lavandula angustifolia, and Salvia fruticosa essential oils against human pathogenic fungi. J. Agric. Food Chem., 46, 1739-1745.

2. Aligianis, N.; Kalpoutzakis, E.; Mitaku, S.; Chinou, I.B. (2001). Composition and antimicrobial activity of the essential oil from Origanum species. J. Agric. Food Chem., 49, 4168-4170.

3. Basilico, M.Z.; Basilico, J.C. (1999). Inhibitory effects of some spices essential oils on Aspergillus ochraceus NRRL 3174 growth and ochratoxin A production. Lett. Appl. Microbiol., 29, 238-241.

4. Battilani, P.; Magan, N.; Logrieco, A. (2006). European research on ochratoxin A in grapes and wine. Int. J. Food Microbiol. 11, S2-S4.

5. Bauer, A.W.; Kirby, W.M.M. (1966)> Antibiotic susceptibility testing by standardized single disk method. Am. J. Clin. Pathol., 45, 493-496.

6. Baydar, H.; Sagdiç, O.; Ozkan, G.; Karadogan, T. (2004). Antibacterial activity and composition of essential oils from Origanum, Thymbra and Sartureja species with commercial importance in Turkey. Food Cont., v.15, n.3, p.169-172. 
7. Brul, S.; Coote, P. (1999). Preservative agents in foods: mode of action and microbial resistance mechanisms. Int. J. Food Microbiol., 50, 1-17.

8. Burt, S. (2004). Essential oils: their antibacterial properties and potential applications in foods - a review. Int. J. Food Microbiol., 94, 223-253.

9. Chun, S.S.; Vattem, A.V.; Lin, Y.T.; Shetty, K. (2005). Phenolic antioxidants from clonal oregano (Origanum vulgare) with antimicrobial activity against Helicobacter pylori. Procces Biochem., 40, 809-816.

10. Daferera, D.J.; Ziogas, B.N.; Polissiou, M.G. (2003). The effectiveness of plant essential oils on the growth of Botrytis cinerea, Fusarium sp. and Clavibacter michiganenesis subsp. michiganenesis. Crop Prot., 22, 39-34.

11. de Billerberk, V.G.; Roques, C.G.; Bessiere, J.M.; Fonvieille, J.L.; Dargent, R. (2001). Effects of Cymbopogon nardus (L.) W. Watson essential oil on the growth and morphogenesis of Aspergillus niger. Can. J. Microbiol., 47, 9-17.

12. Dorman, H.J.D.; Deans, S.G. (2000). Antimicrobial agents from plants: antibacterial activity of plant volatile oils. J. Appl. Bacteriol., 88, 308-316.

13. Graham, H.D. (1982). The Safety of foods. AVI Publishing Company, Connecticuti.

14. Kawashima, L.M.; Valente Soares, L.M. (2006). Incidência de fumonisina $\mathrm{B}_{1}$, aflatoxinas $\mathrm{B}_{1}, \mathrm{~B}_{2}, \mathrm{G}_{1}$ e $\mathrm{G}_{2}$, ocratoxina A e zearalenona em produtos de milho. Ciec. Tecnol. Aliment., 26, 516-521.

15. Leoni, L.A.B.; Furlani, R.F.Z.;Valente Soares, L.M.; Oliveira, P.L.C. (2001). Ocratoxina A em café verde brasileiro. Cienc. Tecnol. Aliment., 21, 105-107.

16. Mares, D.; Tosi, B.; Poli, F.; Andreotti, E.; Romangnoli, C. (2004). Antifungal activity of Tagetus patula on some phytopatogheni fungi ultraestructural evidence on phythum ultimum. Microbiol. Res., 859, 295-304.

17. Marín, S.; Velluti, A.; Ramos, A.J.; Sanchis, V. (2004). Effect of essential oils on zearalenone and deoxynivalenol production by Fusarium graminearum in non-sterilized maize grain. Food Microbiol., 21, 313-318.

18. Midio, A.F.; Martins, D.I. (2000). Toxicologia de Alimentos. Varela, São Paulo.

19. Nostro, A.; Blanco, A.R.; Cannatelle, M.A.; Enea, V.; Flamini, G.; Morelli, I.; Roccaro, A.S; Alonzo, V. (2004). Susceptibility of methicillin-resistant staphylococci to oregano essential oil, carvacrol and thymol. FEMS Microbiol. Lett., 230, 191-195.

20. Novak, J.; Christina, B.; Langbehin, B.; Park, F.; Skoula, M.; Gorsiou, Y.; Franz, C.M. (2000). Ratios of cis- and trans- sabinene hydrate in Origanum marjorana L. and Origanum midrophyllum (Bentham). Biochem. System. Ecol., 28, 697-704.

21. Overy, D.P.; Seifert, K.A..; Savard, M.E.; Frisvad, J.C. (2003). Spoilage fungi and their mycotoxins in commercially marketed chestnuts. Int. J. Food Microbiol., 88, 69-77.
22. Rana, B.K.; Singh, U.P.; Taneja, V. (1997). Antifungal activity and kinetics of inhibition by essential oil isolated from leaves of Aegle marmelos. J. Ethnopharm., 57, 29-34.

23. Rasooli, I.; Abyaneh, M.R. (2004). Inhibitory effect of Thyme oils on growth and afltoxin production by Aspergillus parasiticus. Food Cont., 15, 479-483.

24. Ristori, C.A.; Pereira, M.S.; Gelli, D.S. (2002). O efeito da pimenta do reino moída frente a contaminação in vitro com Salmonella rubislaw. Rev. Inst Adolfo Lutz, 61, 131-133.

25. Roller, S. (1995). The quest for natural antimicrobials as novel means of food preservation status report on a European Research project. Int. Biodet. Biodeg., 35, 3-4, 333-335.

26. Sagdiç, O.; Kusçu, A.; Ozcan, M.; Ozçelik, S. (2002). Effects of Turkish spices extracts at various concentrations on the growth of Escherichia coli O157:H7. Food Microbiol., 19, 473-480.

27. Sahin, F.; Gulluce, M.; Daferera, D.; Sokmen, A.; Polissiou, M.; Agar, G.; Ozer, H. (2004). Biological activities of the essential oils and methanol extract of Origanum vulgare ssp. vulgare in the Eastern Anatolia region of Turkey. Food Cont., 15, 549-557.

28. Saleemullah, A.I.; Khalil, I.A.; Shah, H. (2006). Aflatoxin contents of stored and artificially inoculated cereals and nuts. Food Chem., 98,699-703.

29. Sharma, N.; Tripath, A. (2007). Effects of Citrus (L.) Osbeck epicarp essential oil on growth and morphogenesis of Aspergillus niger (L.) Van Tieghem. Microbiol. Res. In press.

30. Skandamis, P.; Tsigarida, E.; Nichas, G.J.E. (2002). The effect of oregano essential oil on survival/death of Salmonella typhimurium in meat stored at $5^{\circ} \mathrm{C}$ under aerobic, VP/MAP conditions. Food Microbiol., 19, 97-108.

31. Souza, E.L.; Lima, E.O.; Freire, K.R.L.; Sousa, C.P. (2005). Inhibition action of some essential oils and phytochemicals on the growth of moulds isolated from foods. Braz. Arch. Biol. Technol., 48, 245-250.

32. Souza, E.L.; Stamford, T.L.; Lima, E.O. (2006). Sensitivity of spoiling and pathogen-food related bacteria to Origanum vulgare L. (Lamiaceae) essential oil. Braz. J. Microbiol., 37, 527-532.

33. Souza, E.L.; Stamford, T.L.M.; Lima, E.O.; Trajano, V.N. (2007). Effectiveness of Origanum vulgare L. essential oil to inhibit the growth of food spoiling yeasts. Food Cont., 18, 409-413.

34. Utama, J.M.S.; Wills, R.B.H.; Ben-Yehoshua, S.; Kuesk, C. (2001). In vitro efficacy of plant volatiles for inhibiting the growth of fruit and vegetal decay microorganisms. J. Agric. Food Chem., 50, 63716377.

35. Velluti, A.; Sanchis, V.; Ramos, A.J.; Egido, J.; Marin, S. (2005). Inhibitory effect of cinnamon, clove, lemongrass, oregano and palmarose essential oils on growth and fumonisin $\mathrm{B}_{1}$ production by Fusarium proliferatum in maize grain. Int. J. Food Microbiol. 89, 145-154.

36. Wangikar, P.B.; Dwivedi, P.; Sinha, N.; Sharma, A.K.; Telang, A.G. (2005). Effects of aflatoxin $B_{1}$ on embryo fetal development in rabbits. Food Chem. Toxicol., 43, 607-615. 